\title{
COMPLEXO FRATERNO: CONSTITUIÇÃO DO SUJEITO E FORMAÇÃO DO LAÇO SOCIAL
}

\author{
Rebeca Goldsmid
}

Os autores contemporâneos mostraram um interesse maior pelo estudo da relação fraterna por volta do ano 2000. Grande parte desses estudos se dedica mais à competição e à rivalidade entre os irmãos do que à boa convivência e à solidariedade. Em nossa revisão teórica, realizada na abordagem psicanalítica, estudamos a dinâmica da relação fraterna em seus aspectos de disputa e rivalidade, assim como de solidariedade e companheirismo. Constatamos a importância da fratria na constituição do sujeito e na formação do laço social. Ilustramos a discussão teórica com fragmentos de casos de nossa clínica.

\section{BANCA:}

Terezinha Féres-Carneiro (Orientadora)

Edna Lucia Tinoco Ponciano

Lidia Levy de Alvarenga

Data de defesa: 18/12/2009 